Diagnosis of warfarin in samples sent to CIESA during the period 2015-2018.

A recurring problem

\title{
Diagnóstico de warfarina en muestras remitidas al CIESA durante el período 2015-2018. \\ Una problemática recurrente
}

\author{
Valladares-Carranza Benjamín ${ }^{1 *(D)}$, Delgadillo-Ruiz Lucia ${ }^{2}\left(\right.$ Zaragoza-Bastida Adrián $^{3}(\mathbb{D})$, Rivero-Pérez Nallely ${ }^{3}$, \\ Ortega-Santana César ${ }^{1}$ (D), Velázquez-Ordoñez Valente ${ }^{1 *(i)}$
}

\begin{tabular}{l} 
Data of the Article \\
\hline \\
${ }^{1}$ Autonomous Mexico State University. \\
Faculty of Veterinary Medicine and Zootechnics. \\
Mexico. The Cerrillo Piedras Blancas. \\
Toluca, State of Mexico. \\
C.P 50200. 7222965555. \\
Mexico. \\
${ }^{2}$ Autonomous University of Zacatecas. \\
Academic Unit of Biological Sciences. \\
Biotechnology Laboratory. \\
Preparatory avenue s / nolonia Hidráulica. \\
CP. 98068, Zacatecas, Mexico. \\
${ }^{3}$ Autonomous University of the State of Hidalgo. \\
Academic Area of Veterinary Medicine and \\
Zootechnics. \\
Mexico. Av. Universidad km 1 s / n Ex Hacienda. \\
A.P. 32 CP.43600. 7717172000 ext. 2440. \\
Aquetzalpa. Tulancingo de Bravo. Gentleman. \\
Mexico. \\
*Contact address: \\
Autonomous Mexico State University. \\
Faculty of Veterinary Medicine and Zootechnics. \\
Mexico. The Cerrillo Piedras Blancas. \\
Toluca, State of Mexico. \\
C.P 50200. 7222965555. \\
Mexico. \\
Benjamín Valladares-Carranza \\
E-mail address : bvalladaresc@ @uaemex.mx \\
Keywords: \\
Rodenticide, \\
warfarin, \\
poisoning, \\
dog, \\
thin layer chromatography. \\
\hline vve \\
\hline
\end{tabular}

J. Selva Andina Anim. Sci. 2021; 8(1):12-21. ID of article: $086 / \mathrm{JSAAS} / 2020$

\section{Record from the article}

Received October 2020 Returned December 2020

Accepted January 2021.

Available online, April 2021

\section{Edited by: Selva Andina Research Society}

The objective of this work was to determine the number of diagnosed cases of warfarin, used to control or combat "pests" (rodents), in order to highlight the importance of the proper use and application of this substance at the agricultural and even domestic level. There was a total of 21 samples, which corresponded to: Liver, gastric content, and prepared baits, sent to the Toxicology area of the Center for Research and Advanced Studies in Animal Health (CEISA), in the period 2015-2018, the determination of warfarin was carried out through thin layer chromatography, and the descriptive method was used to report the results. The percentage of positivity to warfarin in the study period was $71.41 \%$. The largest number of samples were livers (14 samples), of which 10 (47.61\%) were positive; followed by gastric content with 3 positives (14.28 \%), and prepared baits (pieces of chicken meat, sausages, and ham) with $2(9.52 \%)$. In the applications per year, in 2017 and 2018 they increased, with 6 and 9 cases, of which 5 and 7 were positive for warfarin (23.81 and $33.33 \%$ ), respectively, 3 samples (livers) were collected and sent from the autopsy area of CIESA, where evidence of lesions suggestive of warfarin intoxication was shown. Under the conditions of occurrence and presentation of cases of warfarin poisoning, it is necessary to regulate the commercialization not only of rodenticides, but of all agricultural products that are currently commercialized, to minimize the risk of poisoning in the different animal species and even to avoid the harmful effect on public health and the environment.

2021. Journal of the Selva Andina Animal Science ${ }^{\circledR}$. Bolivia. All rights reserved.

\section{Resumen}

El objetivo del presente trabajo fue determinar el número de casos diagnosticados de warfarina, empleada para el control o combate de "plagas" (roedores), con la finalidad de remarcar la importancia del adecuado uso y aplicación de esta sustancia a nivel agropecuario e incluso doméstico. Un total de 21 muestras, las cuales correspondieron a: hígado, contenido gástrico y cebos preparados, enviados al área de Toxicología del Centro de Investigación y Estudios Avanzados en Salud Animal (CIESA), en el periodo 2015-2018, la determinación de warfarina se realizó a través de cromatografía en capa fina, y para el reporte de resultados se usó el método descriptivo. El porcentaje de positividad a warfarina en el periodo de estudio fue del $71.41 \%$. El mayor número de muestras fueron hígados (14 muestras), de las cuales $10(47.61 \%)$ resultaron positivas; seguidos del contenido gástrico con 3 positivas (14.28 \%), y los cebos preparados (piezas de carne de pollo, salchichas y jamón) con 2 (9.52 \%). En las solicitudes por año, en el 2017 y 2018 se incrementaron, con 6 y 9 casos, de los cuales 5 y 7 fueron positivos a warfarina (23.81 y $33.33 \%$ ), respectivamente, 3 muestras (hígados), fueron colectados y enviados del área de necropsias del CIESA, en donde se mostró la evidencia de lesiones sugestivas de intoxicación por warfarina. Bajo las condiciones de ocurrencia y presentación de los casos de intoxicación por warfarina es necesario regular la comercialización no solo de rodenticidas, sino de todos los productos agropecuarios que se comercializan actualmente, con el objeto 


\begin{tabular}{l||l}
\hline Palabras clave: & $\begin{array}{l}\text { de minimizar el riesgo de intoxicación en las diferentes especies animales e incluso para evitar el efecto nocivo en } \\
\text { salud pública y al ambiente }\end{array}$ \\
$\begin{array}{l}\text { Rodenticida, } \\
\text { warfarina, } \\
\text { intoxicación, } \\
\text { perro, } \\
\text { cromatografía en capa fina. }\end{array}$ & 2021. Journal of the Selva Andina Animal Science ${ }^{\circledR}$ Bolivia. Todos los derechos reservados. \\
\hline
\end{tabular}

\section{Introduction}

Currently in different spaces such as the agricultural and even domestic industry, the use of so-called rodenticides is required, defined as biocidal products used for the control of rodents, substances that are specifically designed for the elimination of rodents ${ }^{1,2}$. However, since these animals generally share the environment with humans, other mammals and a variety of birds, the risk of accidental poisoning can occur with the placement of rodent baits ${ }^{2,3}$, in addition, due to the abuse in the use of these products, rodents have been developing resistance to rodenticides, therefore, at a commercial level, new rodenticides with a higher toxic potential have been generated and produced, so appropriate criteria are required. and correct use of these substances, since in some cases the induction of an intoxication process in dogs is mainly caused deliberately $\mathbf{4}, \underline{5}$.

Warfarin is an oral anticoagulant substance used in medicine to prevent the formation of thrombi and emboli, inhibits the production of vitamin K-dependent clotting factors, reducing the ability of blood to clot. It is derived from the natural anticoagulant mycotoxin dicoumarol found in sweet clover. Coumarins and their derivatives are used as rodenticides for the control of rodents in residential, industrial, and agricultural areas ${ }^{\underline{6}}$, it is an odorless, colorless and tasteless product, which is why it is effective when used $\stackrel{4,5,7}{ }$.

With the discovery of warfarin, the appearance and overuse of other anticoagulants such as rodenticides, 13 an attempt has been made to increase its efficacy and safety in rodent control programs, due to its slow action, the existence of an antidote-to for chronic action rodenticides and to reduce the use of poisons with acute effects, due to the danger they imply from handling to application or use $\mathrm{e}^{8,9}$.

The so-called coumarins, derived from 4-hydroxycoumarin, most commonly used are warfarin and acenocoumarol. In humans, warfarin was used since 1960 for the treatment of thrombotic disorders or oral anticoagulants, as a synthetic derivative of coumarin, it exhibits a competitive action against vitamin $\mathrm{K}$ and inhibits the synthesis of the enzyme epoxide reductase-Vitamin $\mathrm{K}$-dependent coagulation agents (II, VII, IX, and X) $\underline{10}$.

Warfarin (coumadin) substance of short duration, used in the manufacture of rodenticides. It can be presented in a solid or powder crystalline form, slightly soluble in water, its acute toxicity for humans $\mathrm{LD}_{50}$ : $500-5000 \mathrm{mg} / \mathrm{kg}$, acts by disturbing the normal mechanisms of blood clotting in both humans and animals 11 .

Warfarin is a racemic mixture of two optically active isomers (enantiomers): form ( $\mathrm{S}$ and $\mathrm{R}$ ), $\mathrm{S}$ is five times more potent as a vitamin $\mathrm{K}$ antagonist than the $\mathrm{R}$ form. Warfarin does not act in the circulation, but in the liver and acts only in vivo, which is why it is considered an indirect coagulation precursor, unlike heparin, which acts in vivo and in vitro as a direct anticoagulant agent. It has no action on a thrombus 
and its effect is not immediate, but it prevents new thrombi from continuing to form or from becoming more extensive. The metabolism of this substance is carried out through the enzymatic system of the cytochrome P450 subfamily (CYP2C9), whose mutations are decisive in the therapeutic response to warfarin $\underline{5}, \underline{12}$.

The binding of warfarin to proteins is $99 \%$, therefore, it is decisive in drug interactions, since only the free fraction is active. Its anticoagulant properties are enhanced with some drugs because albumin has the property of being occupied and displacing the substance, as well as those drugs dependent on cytochrome P450, in the same way, they would have effects on its plasma concentration ${ }^{8}, \underline{13}$.

The objective of this work was to determine the number of diagnosed cases of warfarin, used for the control or combat of rodent pests, and in which poisoning problems are often observed in domestic animals such as dogs, with the aim of to highlight the importance of the proper use and application of this substance at the agricultural and even domestic level.

\section{Materials and methods}

For the present study, 21 requests were used - clinical records (of liver samples, prepared baits, and gastric content), sent to the toxicology area of the Center for Research and Advanced Studies in Animal Health (CRASAS) of the Faculty of Veterinary Medicine and Zootechnics (FVMZ), in the period 2015-2018, in order to detect the presence of warfarin given the conditions or appearance of the baits or preparations in a suspicious way on the premises or symptoms observed and referred by the owners in some intoxi- cated dogs (pale mucous membranes, epistaxis, and melena) where some of these were said to have died. By combining the information from the toxicology area (clinical histories/report of the results of the cases), as well as samples sent to the area (where the processing for the diagnosis was participated in), the report was carried out as follows. as complete as possible, with the understanding that some cases initially passed through the autopsy area and photographic evidence of lesions suggestive of warfarin intoxication could be obtained.

Determination of warfarin by thin-layer chromatography. Chromatography is a method of analysis and separation of the various components of a substance, based on the different distribution of these components in two phases, the stationary phase (silica gel) and the mobile phase (warfarin developer). to separate and move through the stationary phase, for the analysis $25 \mathrm{~g}$ or $25 \mathrm{~mL}$ of sample (liver, stomach content, or whole blood) are required, which through the addition of different substances (acidified ethyl alcohol, ether, distilled water, $1 \%$ sodium pyrophosphate, $4 \mathrm{~N}$ sulfuric acid and anhydrous sodium sulfate) the analyte is separated and obtained in the analyzed sample, it is evaporated to dryness at an approximate temperature of $40^{\circ} \mathrm{C}$, is resuspended with $500 \mu \mathrm{L}$ of ether and applied to the thin layer chromatography plate 10,20 and $50 \mu \mathrm{L}$ of the sample, as well as 10, 20 and $50 \mu \mathrm{L}$ of warfarin standard. The plate is developed with the specific developer and before the developer reaches $2 \mathrm{~cm}$ from the upper edge of the plate it is removed and allowed to dry at room temperature. Subsequently, it is observed with the UV light lamp in a dark room, recording the retention factor $(\mathrm{RF})$ of the spots that appeared ${ }^{14}$. For the report 
of results, the descriptive method was used (tables and figures $)^{15}$.
The percentage of positivity to warfarin of the sam-

ples sent in the study period was $71.41 \%$ (table 1).

\section{Results}

Table 1 Type of samples and positivity to warfarin (\%)

\begin{tabular}{ccccc}
\hline Type of sample & Number & Percentage & Positive for warfarin & Percentage of positives \\
\hline Liver & 14 & 66.66 & 10 & 47.61 \\
Gastric content & 5 & 23.81 & 3 & 14.28 \\
Prepared baits & 2 & 9.52 & 2 & 9.52 \\
Total & $\mathbf{2 1}$ & $\mathbf{1 0 0}$ & $\mathbf{1 5}$ & $\mathbf{7 1 . 4 1}$ \\
\hline
\end{tabular}

The highest number of samples sent corresponded to livers with a total of 14 samples, of which 10 (47.61 $\%$ ) were positive for warfarin, followed by gastric content with 3 positive (14.28\%), and the prepared baits (pieces of meat from chicken, sausages, and ham) with $2(9.52 \%)$.

Of all the cases, the samples were related to the dogs, which the owners transferred to the laboratory, due to the occurrence of "sudden" death of the animals or the appearance of suspicious material (baits) that were placed or "thrown" "To the places where the animals are usually found (corrals, backyard, or found on the street or in someplace close to the habitat of a dog), the requests for toxicological analysis per year, although it is numerically varied, in the 2017 and 2018 increased, with the request of 6 and 9 cases, of which 5 and 7 were positive for warfarin (23.81 and $33.33 \%)$, respectively (table 2 ).

Table 2 Number of cases requested per year for warfarin detection

\begin{tabular}{cccc}
\hline Year & Number of samples & Warfarin positive samples & Percentage of positive samples \\
\hline 2015 & 3 & $2(66.66 \%)$ & 9.52 \\
2016 & 3 & $1(33.33 \%)$ & 4.76 \\
2017 & 6 & $5(83.33 \%)$ & 23.81 \\
2018 & 9 & $7(77.77 \%)$ & 33.33 \\
Total & $\mathbf{2 1}$ & $\mathbf{1 5}$ & $\mathbf{7 1 . 4 1}$ \\
\hline
\end{tabular}

Of the particular requests for samples sent to the toxicology area, 3 of them (livers) were collected and sent from the CRASAS autopsy area, where evidence of lesions suggestive of warfarin intoxication was reported (figure 1).

In one of the cases where the diagnosis of warfarin positivity was made in the liver of a dog (a 3-yearold female, weighing $30 \mathrm{~kg}$ ), reporting prostration, vomiting with a crystalline foamy appearance, and that finally died. The pathological study revealed pleural and pericardial adhesions, Petechial and subepicardial ecchymotic hemorrhages in atria and blood vessels (figure 1 and 2), right ventricular dilation (figure 3), hepatomegaly, hemorrhagic gastroenteritis, multiple hemorrhages in internal organs: lung, heart, liver, kidney, stomach, and intestine (figures 4 and 5). 
Figure 1 Dog dissection in necropsies room. Neck ventral region and, subcutaneous tissue hemorrhagic pectoral and, uncoagulated blood (yellow arrow)

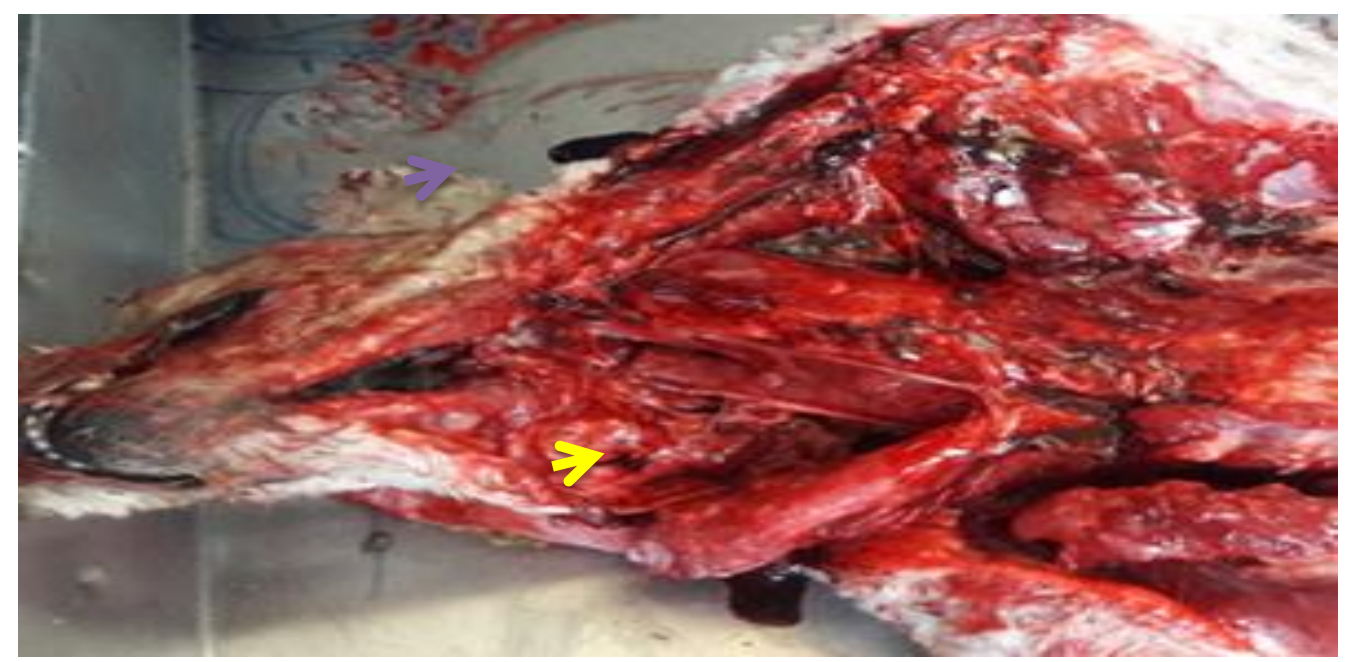

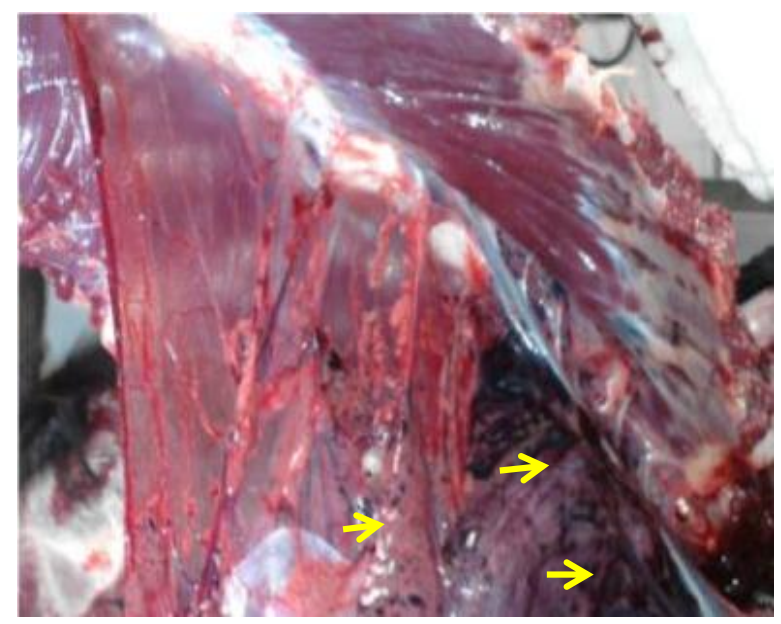

Figure 2 Ventral region thoracic cut. Pleural and, pericardial adherence was observed in the sternum, equimotic hemorrhages in the pericardic zone

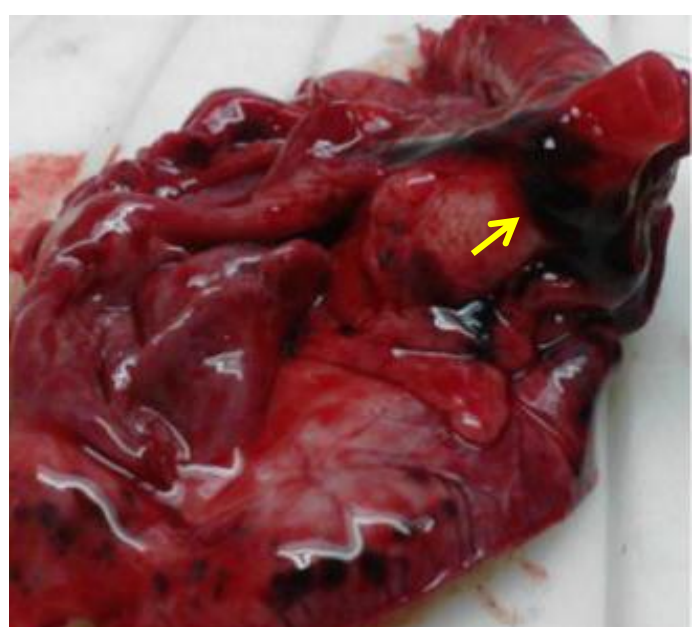

Figure 3. Heart surface. Petechial and sub-pericardial equimotic hemorrhages were observed in atriums and blood vessels

\section{Discussion}

According to the percentage of positivity to warfarin, it is considered that this value was high and that it determines the inappropriate or excessive use for the "control" of rodents, this because if there were proper management and placement of baits or prepared for harmful fauna, there would be no cases affecting species such as dogs or cats. In particular, in the cases that are reported, animals can be accidentally poisoned by ingestion of baits and/or dead rodents contaminated with warfarin $\frac{7,16-20}{}$. Under this condition, in animals that consume this substance circumstantially, the clinical signs observed occur during the following days depending on the dose or quantity ingested, and they present subcutaneous hematomas and epistaxis $4,11,13,16,17,21$. 
In the reports by Werner ${ }^{22}$ and $\operatorname{Jiri}^{23}$, it is mentioned that in the process of intoxication by anticoagulant rodenticides, especially in dogs and cats, the typical clinical signs reported are: depression, weakness, and pale mucous membranes, which are due to

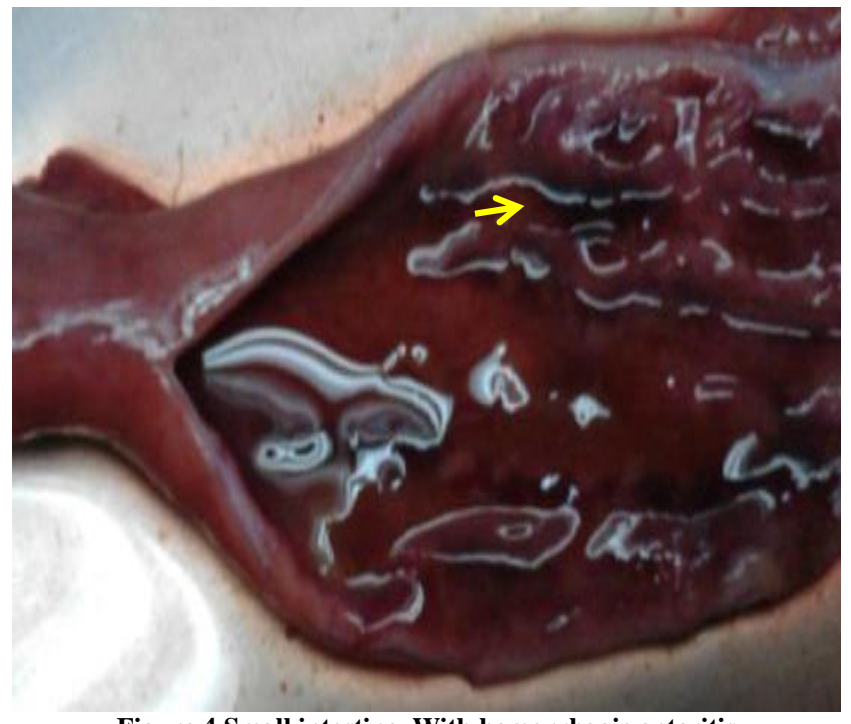

Figure 4 Small intestine. With hemorrhagic enteritis

When considering the toxicokinetics of substances that enter orally, the liver is the organ where, when all metabolic processes are carried out, a high percentage of metabolites of different substances and compounds can be detected, being useful as a sample in the laboratory in most of the clinical and medicallegal cases $\frac{18,19}{}$.

The lesions observed at necropsy are an important guideline to be able to direct the diagnosis more effectively according to Díaz-González et al. ${ }^{24}$, who describe and report the characteristics of subcutaneous hemorrhages in a canine, and refer that the anatomopathological study observed adhesions pleural, pericardial, petechial, subepicardial ecchymotic hemorrhages, in atria and blood vessels, conditions that coincide with those described by Seljetun et al. ${ }^{19}$ hemorrhages, usually within body cavities, or to dysfunctions of one or several organs caused by hypovolemia, and it is feasible to observe, although less frequently, mucosal hemorrhages.

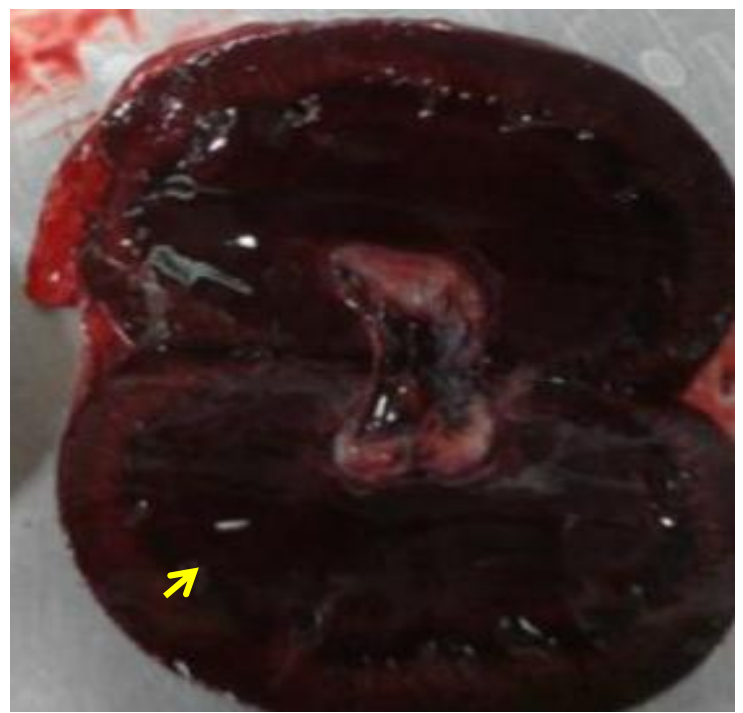

Figure 5 Longitudinal section of the kidney. Severe corticomedullary congestion and Elmeros et al. $\underline{20}$ when cases of warfarin poisoning are evaluated.

In the same study by Díaz-González et al. $\stackrel{24}{ }$, when integrating the diagnostic result, they considered that the macro and microscopic lesions were compatible with a picture of warfarin intoxication, by observing multiple hemorrhages in internal organs: lung, heart, liver, kidney, stomach, and intestine, and liver to histopathological study, observed diffuse centrilobular congestion related to severe liver damage.

In the report made by Montoliu-Stevers \& Camps ${ }^{25}$, of a case of hemopericardium in a dog poisoned by anticoagulant rodenticides, in which the diagnosis made was that of hemorrhagic pericardial effusion, under urgent medical criteria they performed a guided pericardiocentesis to treat Cardiogenic shock, 
in this work it is proposed that the differential diagnosis, similar to the one treated, should include idiopathic hemorrhagic pericardial effusion, trauma, intracardiac neoplasia and coagulopathy (disseminated intravascular coagulopathy (DIC), rodenticide poisoning and liver disease).

According to the diagnostic route of the case, it is important to collect the appropriate samples to determine or confirm the result of the laboratory that is issued, as well as for the treatment to be established in the patient, in this context, Montoliu-Stevers \& Camps $\underline{25}$, took and collected blood for hemogram, complete clinical biochemistry, prothrombin time (PT), activated partial thromboplastin time (PTT), and urine sample for a general urine examination, the result of these analyzes denoted a marked increase of prothrombin time and activated partial thromboplastin time which indicated the presence of coagulopathy, in the hemogram anemia and thrombocytopenia were reported, in the biochemistry: azotemia and hypoproteinemia, and in the urinalysis they detected hematuria.

It is worth mentioning that in the face of an intoxication process by anticoagulant rodenticides when there is still time and a way to care for the patient by a veterinarian, it is feasible to take him to his recovery, this, according to the appropriate diagnostic route, it is possible to perform therapeutic management adequate $\mathrm{2}^{26,27}$. Considering that in the occurrence of similar cases, PT and PTT can be controlled and returned to normal values after the start of treatment with vitamin $\mathrm{K} 1$, clotting times can decrease significantly, indicating that hemostatic problems occur due to antagonism of vitamin $\mathrm{K}$. In addition, the monitoring and evaluation of the affected patient during the following days (two or more) should be con- sidered, in order to rule out the recurrence of the pericardial effusion; and continue with the oral administration of vitamin $\mathrm{K} 1$ for a month, under the supervision of a specialist $\frac{26}{}$. Therefore, for treatment the application of intravenous fluid therapy (Ringer's lactate, maintenance rate), ranitidine (melena), B complex, and vitamin $\mathrm{K} 1$ is essential $\underline{3,6,2 \underline{, 2}, 29}$.

Once adverse effects have occurred and finally caused the death of the individual (dog), the anatomopathological study, macroscopic and microscopic changes can be observed that consist mainly of generalized hemorrhages in several organs, so an adequate differential diagnosis must be made which should also include vitamin $\mathrm{K}$ deficiency in relation to treatment with chemotherapy for prolonged periods, poisoning by zinc phosphide or aflatoxins,

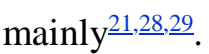

With the data obtained in the present study, once warfarin was identified in the analytical process as a substance that caused death in some of the dogs, as well as its determination in the "baits" found by the owners, it is feasible that they are not an accidental process, but rather a deliberately induced process, which is why it is necessary to regulate the commercialization not only of rodenticides but of all agricultural products that are currently commercialized, this in order to minimize the risk of accidental or induced poisoning in the different animal species and even to avoid the harmful effect on public health and the environment.

\section{Funding source}

Research Center and Advanced Studies in Animal Health (CIESA). Faculty of Veterinary Medicine and Zootechnics (FMVZ). Autonomous Mexico State University. 


\section{Conflicts of interest}

The authors declare there are not any potential interest conflicts with research, authoring, and/or publishing this article.

\section{Acknowledgments}

To Research Center and Advanced Studies in Animal Health (CIESA). Faculty of Veterinary Medicine and Zootechnics (FMVZ). Autonomous Mexico State University, by equipment, material, substances and, the infrastructure supporting analytic determinations. To M en C Ada Díaz González Borja and M en C Jose Luis Zamora Espinoza by photografic material support.

\section{Ethical considerations}

Carcass evaluations were made according to methodological procedures provided by some authors (Necropsy manual. Faculty of Veterinary Medicine and Zootechnics (FMVZ), Autonomous University of the State of Mexico.).

\section{Authors' contribution to the article}

Benjamin Valladares Carranza: processing and laboratory samples analysis, writing, redaction, revision, and edition to the article. Lucia Delgadillo Ruiz methodology, analysis, revision, and edition to the article. Adrian Zaragoza Bastida and Nallely Rivero Pérez, redaction, and draft preparation. Cesar Ortega Santana research information about theme and conceptualization. Valente Velazquez Ordoñez researching and revisión

19

\section{Cited Literature}

1. Memmott K, Murray M, Rutberg A. Use of anticoagulant rodenticides by pest management professionals in Massachusetts, USA. Ecotoxicology 2017;26(1):90-6. DOI: https://doi.org/10.1007/s 10646-016-1744-5

2. Berny P. Pesticides and the intoxication of wild animals. J Vet Pharmacol Ther 2007;30(2):93100. DOI: https://doi.org/10.1111/j.13652885. 2007.00836.x

3. DeClementi C, Sobczak BR. Common rodenticide toxicoses in small animals. Vet Clin North Am Small Anim Pract 2018;48(6):1027-38. DOI: https://doi.org/10.1016/j.cvsm.2018.06.006

4. Gupta CR, Fact D. Veterinary toxicology. Basic and clinical principles. Gupta CR, editor. San Diego: Academic Press; 2007. 525 p.

5. Castelhanos Rojas R, Ferrer Herrera IM, Segura Pujal LA, Ojeda Matías MR, Alfonso Hernández MC. Resistencia y sensibilidad a la warfarina. AMC 2014;18(2):226-39.

6. Watt BE, Proudfoot AT, Bradberry SM, Vale JA. Anticoagulant rodenticides. Toxicol Rev 2005;24 (4):259-69. DOI: https://doi.org/10.2165/001397 09-200524040-00005

7. Rattner BA, Lazarus RS, Elliott JE, Shore RF, van den Brink N. Adverse outcome pathway and risks of anticoagulant rodenticides to predatory wildlife. Environ Sci Technol 2014;48(15):8433-45. DOI: https://doi.org/10.1021/es501740n

8. Yurgaky J, Rodríguez F. Warfarina: uso contemporáneo. Rev Fac Med 2009;17(1):107-15.

9. Feinstein DL, Akpa BS, Ayee MA, Boullerne AI, Braun D, Brodsky SV, et al. The emerging threat of superwarfarins: history, detection, mechanisms, and countermeasures. Ann N Y Acad Sci 
2016;1374(1):111-22. DOI: https://doi.org/10. 1111/nyas.13085

10.Chong YK, Mak TW. Superwarfarin (Long-Acting anticoagulant rodenticides) poisoning: from pathophysiology to laboratory-guided clinical management. Clin Biochem Rev 2019;40(4):17585. DOI: https://doi.org/10.33176/AACB-19-000 $\underline{29}$

11.Buck WB, Osweiler GD, Van Gelder GA. Toxicología veterinaria clínica y diagnóstica. Zaragoza: Acribia; 1969.

12.Spahr JE, Maul JS, Rodgers GM. Superwarfarin poisoning: a report of two cases and review of the literature. Am J Hematol 2007; 82(7):656-60. DOI: https://doi.org/10.1002/ajh.20784

13.Ng WY, Ching CK, Chong YK, Ng SW, Cheung WL, Mak TWL. Retrospective study of the characteristics of anticoagulant-type rodenticide poisoning in Hong Kong. J Med Toxicol 2018;14(3):218-28. DOI: https://doi.org/10.1007 /s13181-018-0660-x

14. Valladares CB. Manual de Practicas: Toxicología. Facultad de Medicina Veterinaria y Zootecnia. UAEM. 2018.

15.Wayne D. Bioestadística. Base para el análisis de las ciencias de la salud. Mexico: Noriega Editores; 2000.

16. Murphy MJ. Anticoagulant rodenticide. In: Gupta RC, editor. Veterinary toxicology basic and clinical principles. San Diego: Academic Press; 2007. p. 527-47. DOI: https://doi.org/10.1016/B978$\underline{012370467-2 / 50145-0}$

17.Jain AV._Sample submission for toxicological análisis. In: Gupta RC, editor. Veterinary toxicology basic and clinical principles. San Diego: Academic Press; 2007. p. 1077-82. DOI: https://doi.org/10.1016/B978-012370467-2/501 $\underline{84-X}$
18. Sobestiansky J, Mores N, Souza MA, Moreno AM. Intoxicação por minerais, produtos químicos, plantas e gases. In: Sobestiansky J, Barcellos D, editors. Doenças dos suínos. $2^{\mathrm{a}}$ ed. Goiânia: Cânone; 2012.

19.Seljetun KO, Vindenes V, Øiestad EL, Brochmann GW, Eliassen E, Moe L. Determination of anticoagulant rodenticides in fae-ces of exposed dogs and in a healthy dog po-pulation. Acta Vet Scand 2020;62:30. DOI: https://doi.org/10. 1186/s13028-020-00531-5

20.Elmeros M, Christensen TK, Lassen P. Concentrations of anticoagulant rodenticides in stoats Mustela erminea and weasels Mustela nivalis from Denmark. Sci Total Environ 2011;409 (12):2373-8. DOI: https://doi.org/10.1016/j.scitotenv.2011.03.006

21.Kalinin S, Marangoni N, Kowal K, Dey A, Lis K, Brodsky $\mathrm{S}$, et al. The long-lasting rodenticide brodifacoum induces neuropathology in adult male rats. Toxicol Sci 2017;159(1):224-37. DOI: https://doi.org/10.1093/toxsci/kfx134

22.Werner PR. Patología general veterinária aplicada. São Paulo: Roca; 2001.

23.Jiri P. Strychnine. In: Gupta RC, editor. Handbook of toxicology of chemical warfare agents. Londres: Academic Press; 2009. p. 215-22. DOI: https://doi.org/10.1016/B978-0-12-800159-2-000 $\underline{16-6}$

24.Díaz González BAE, Zamora EJL, Valladares CB, Velázquez OV. Estudio de un caso clínico de intoxicación por warfarina en un canino. Estado de la Patología Veterinaria en México. Investigación 2015.

25.Montoliu Stevers P, Camps PM. Hemopericardio en un perro intoxicado por rodenticidas anticoagulantes. Rev AVEPA [Internet]. 2012 [citado 5 de octubre de 2020]; 2: 144. Recuperado a partir de: 
https://ddd.uab.cat/pub/clivetpeqani/11307064v2 2n2/11307064v22n2p144.pdf

26.Daza MA, Ayuso E. Intoxicaciones más frecuentes en pequeños animales. Rev AVEPA 2004;24(4):231-9.

27.Couto G, Nelson W. Medicina interna de animales pequeños. $3^{\mathrm{a}}$ ed. Buenos Aires: Intermedica; 2005. p. 1269-70.

28.Iglesias Lepine ML, Epelde Gonzalo F, Casañas Ferrer F, Gené Tous E. Intoxicación por rodenticidas superwarfarínicos en adultos: bromadiolona, brodifacoum y difetialona. Emergencias 2013;25 (3):201-3.
29. Watt BE, Proudfoot AT, Bradberry SM, Vale JA. Anticoagulant rodenticides. Toxicol Rev 2005;24(4):259-69. DOI: https://doi.org/10.2165/ $\underline{\text { 00139709-200524040-00005 }}$

Editor's Note:

Journal of the Selva Andina Animal Science (JSAAS) remains neutral with respect to jurisdictional claims published on maps and institutional affiliations. 